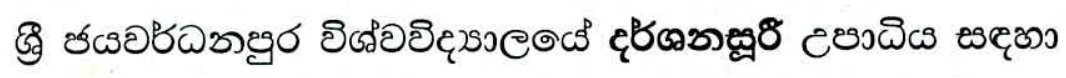

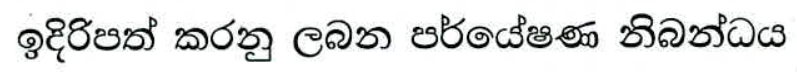

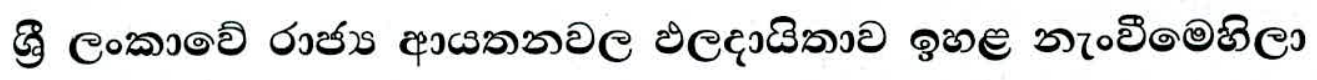

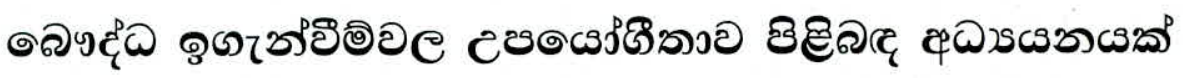

ऊอ

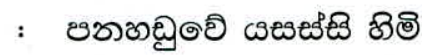

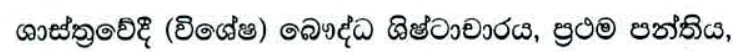

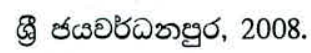

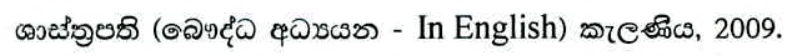

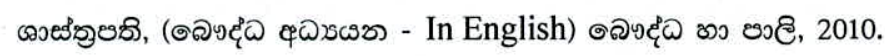

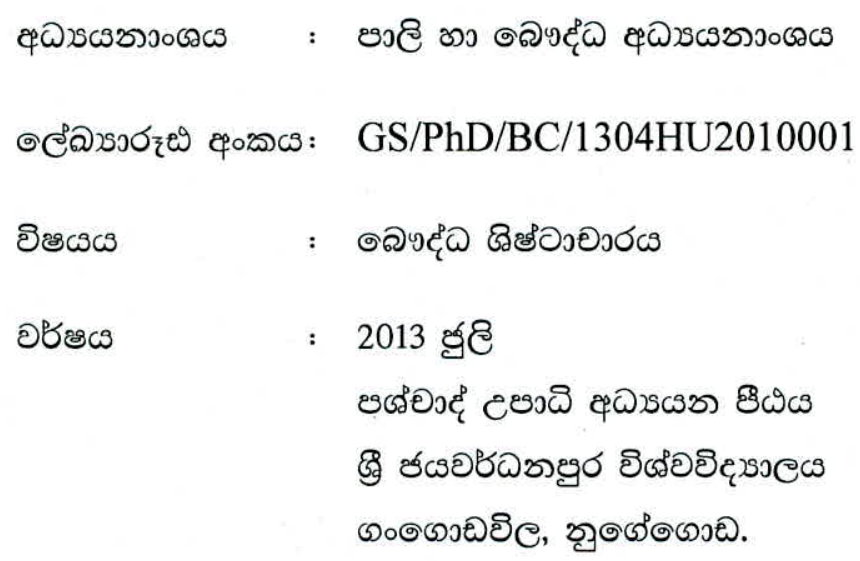




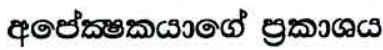

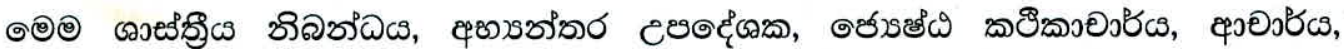

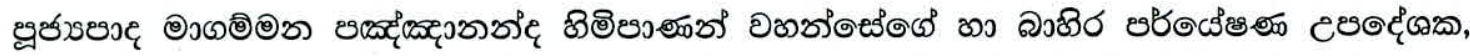

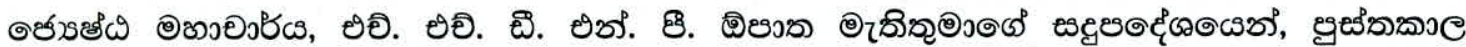

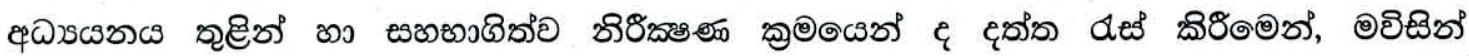

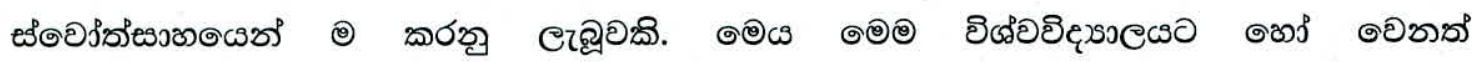

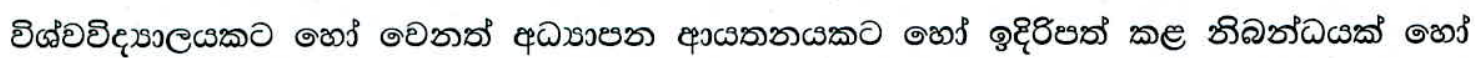

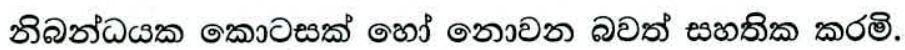

๑๑ఱం,

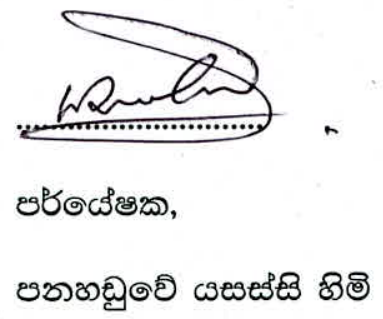

$\mathrm{GS} / \mathrm{PhD} / \mathrm{BC} / 1304 \mathrm{HU} 2010001$ 


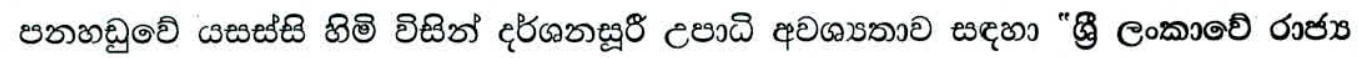

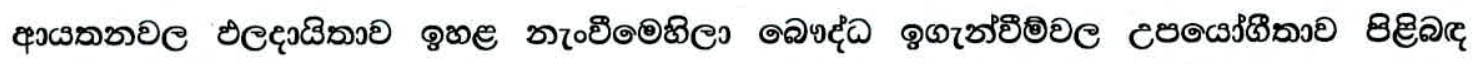

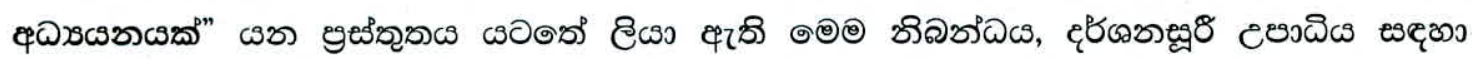

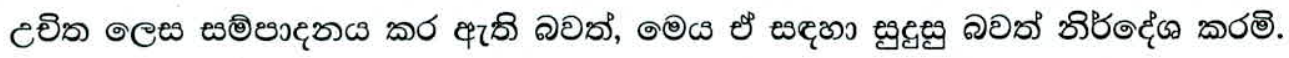

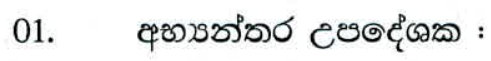

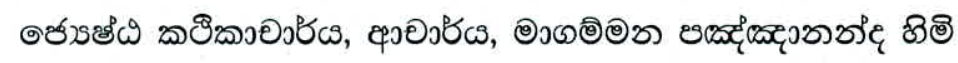

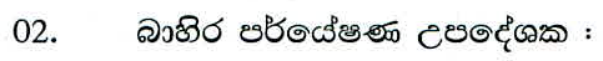

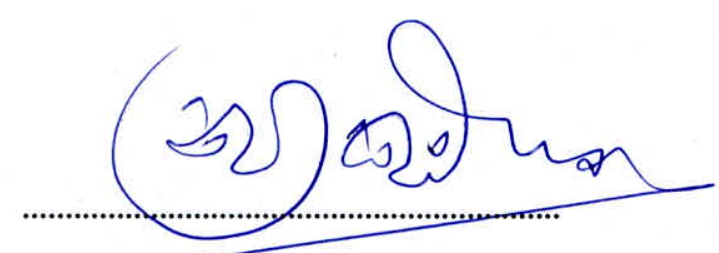

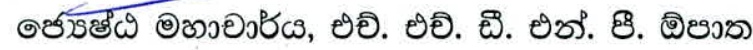

Senior Prof. Dr.H.H.D.N.P.Opatha

BSC(BA)Sp(tons) (USJ);MSC(BA)HRM(USJ)

MBA(Birminghami: nin IR\&PM (CTC);

DIP Eny (CPM): PhD (HRMXUUM);

DHRMM(IU):HAMIOM (SL);CUBA (OXIM-UK)

\section{Senior Professor}

Department of Human Resource Management

Faculty of Managemen* s.",tins and Commerce

University of Sri Jayewarnenepura

Nugegoda

Sri Lank: 


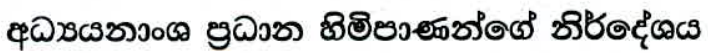

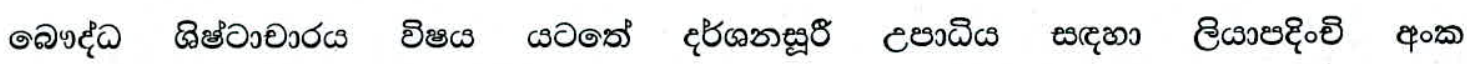

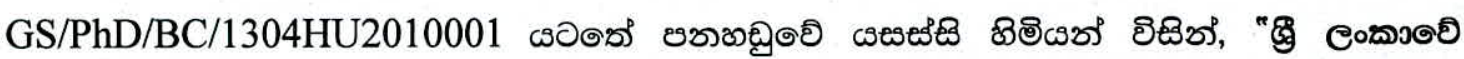

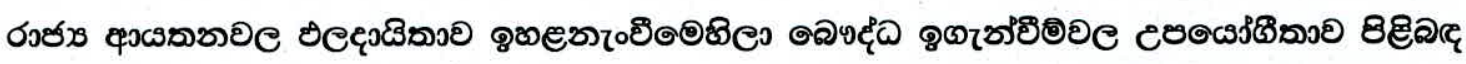

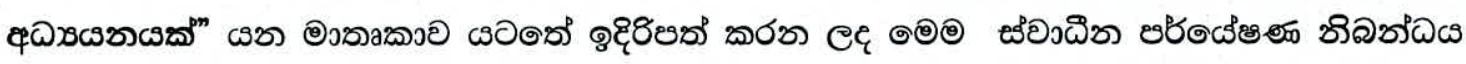

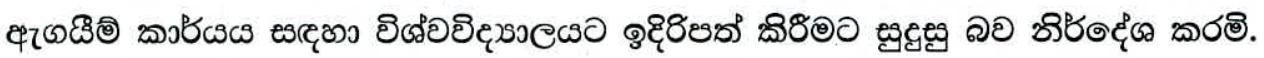

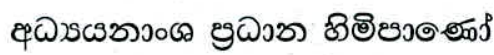

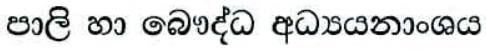




\section{ชิตูอ}

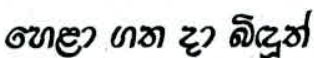

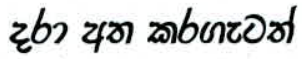

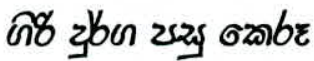

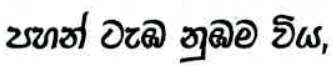

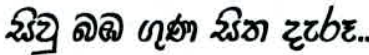

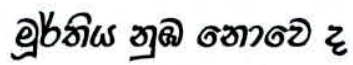

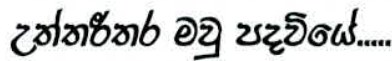

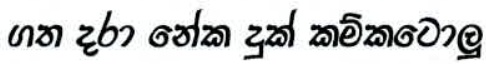

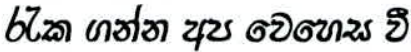

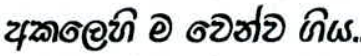

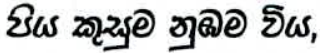

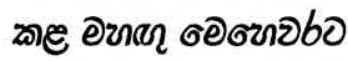

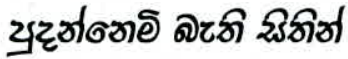

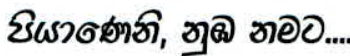

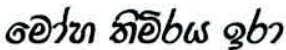

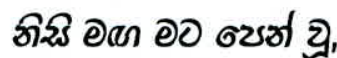

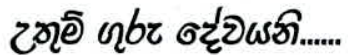

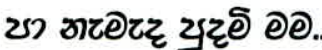

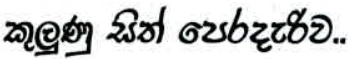




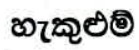

\begin{tabular}{|c|c|}
\hline రిలణ్రదివు జింవలోరి & - లిఅటిం \\
\hline 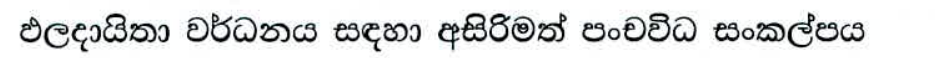 & - రిలఢణణిం \\
\hline జింరిదงร อళఁง & - ఱింอరడి \\
\hline 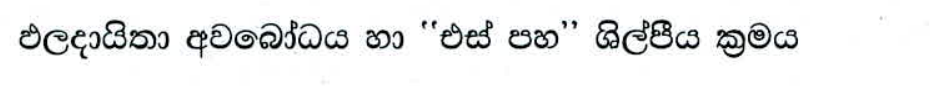 & - రిఁఢా \\
\hline 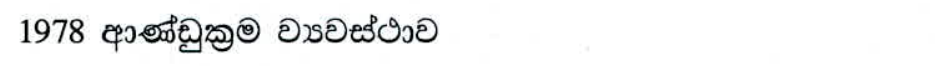 & - ६อองอ \\
\hline 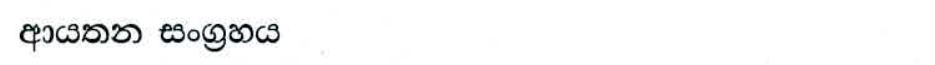 & - ६ొЈటిం \\
\hline 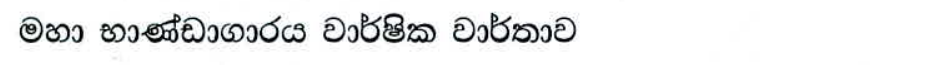 & 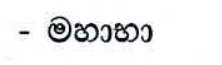 \\
\hline 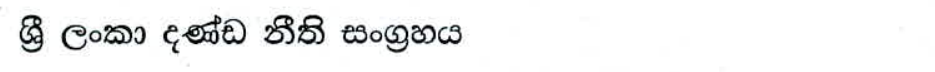 & - દૃळటణం \\
\hline జిరిలో కోవి జింద్రండ & - ๒ిలిలోటిం \\
\hline 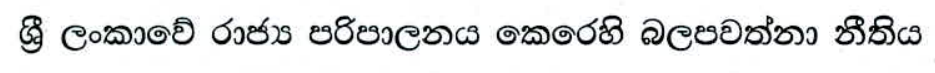 & - бง88อ৫39 \\
\hline 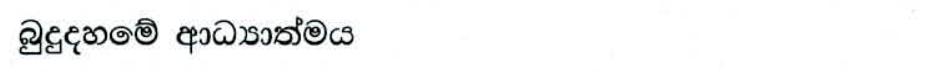 & - இ्वृद्वक्ग \\
\hline 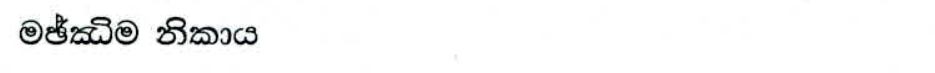 & - ๑ßి \\
\hline 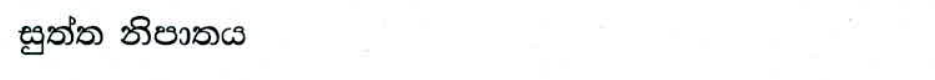 & - ๕్రЗి \\
\hline 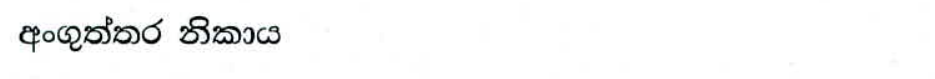 & - ఢ०ßి \\
\hline 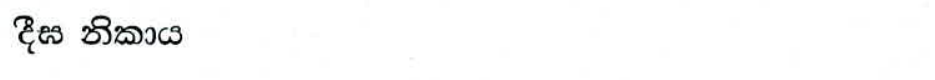 & - ६ุ̧ి \\
\hline 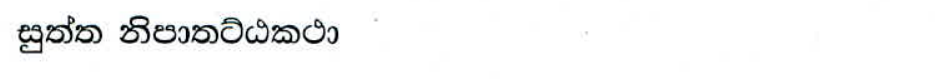 & - ๕్రઝిథ్ \\
\hline மఠిఠఠక̨ణ & - ఏళ \\
\hline 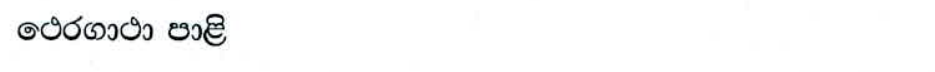 & - - ৩৩ర \\
\hline 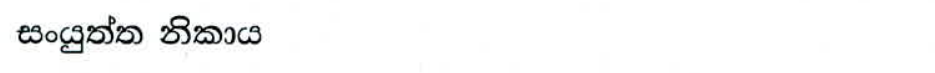 & - ఱం:ి \\
\hline రిడ్రికిది అృరండి & - రిఅ๐ \\
\hline జ్రరిణి అం అాయడు & - દ్রిఠQ \\
\hline జ్రఠుతిను & - జ్రిలం \\
\hline 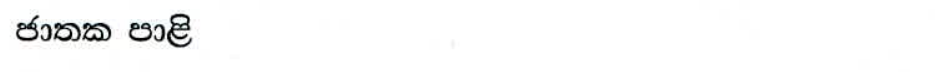 & - రువు \\
\hline 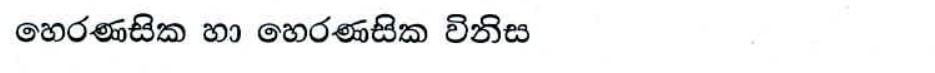 & - ఠంరరల్ \\
\hline 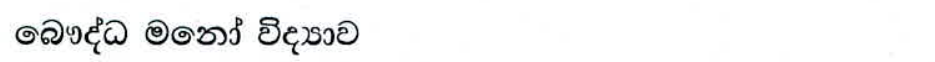 & - ๑ఎッ๑రి \\
\hline
\end{tabular}




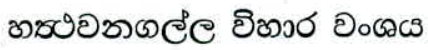

$-3000$

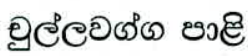

- అతீల

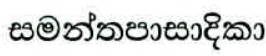

- ผ8ชง

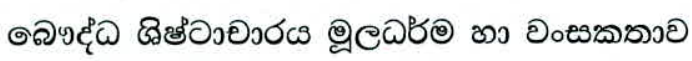

- ๑องడెอ్ูอ

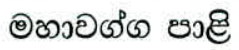

- ๑30

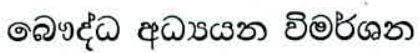

- ๑ลต๕రิ

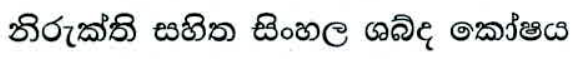

- ชిణิంตంอుల

P.T.S Pali English Dictionary

- PED

English Pali Dictionary

- EPD

A Pali English Glossary of Buddhist Technical Terms

- PEDBTT

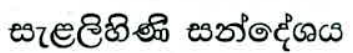

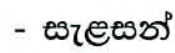

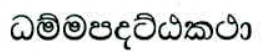

- ఏళ६ఢ

อุ้อ อรณพ

- ออ

टદุ๐ ชา

- टеุ

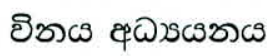

- రిథ

ชชองర ชา

$-88$

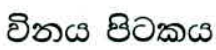

- ฮిత

ชวชวช์ฉ ชృ

- вэбэ

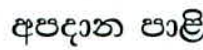

- ६8

Process of Management

- PM

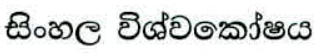

- ๒ింరి

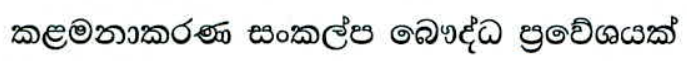

- వeణి

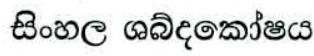

- టింตลิ

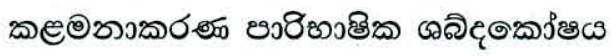

- వยษงเวลิ

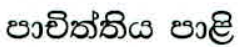

- ชงలิ

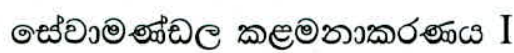

- ๑ఱోอง I 


\begin{tabular}{|c|c|}
\hline 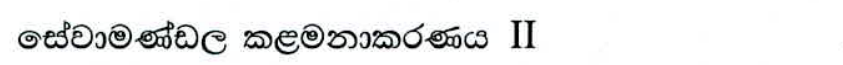 & - ఠఱోอง II \\
\hline 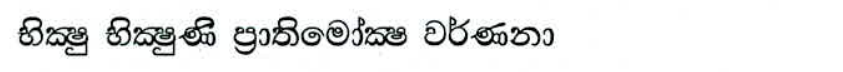 & - छ్రందిอళ \\
\hline 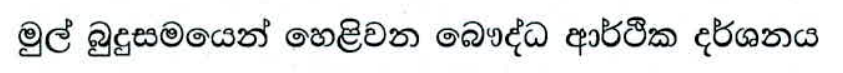 & 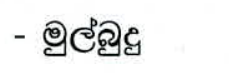 \\
\hline 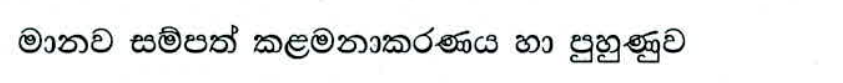 & - อொவை \\
\hline Personal Quality & $-\mathrm{PQ}$ \\
\hline Civil Service Administration in Sri Lanka & - Civil \\
\hline Human Resource Management & - HRM \\
\hline Strategic Human Resource Management & - Str HRM \\
\hline 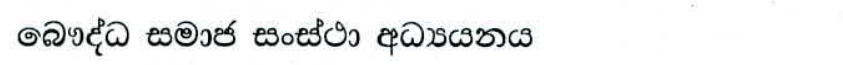 & - ๑อりผณњం \\
\hline 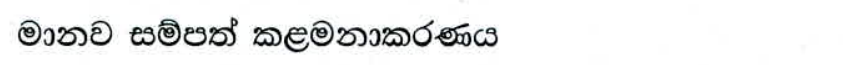 & - องesను \\
\hline 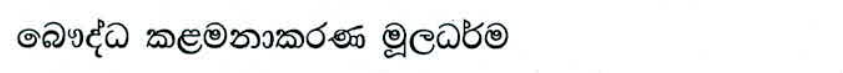 & 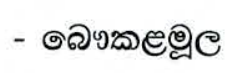 \\
\hline 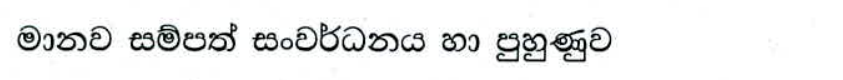 & 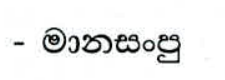 \\
\hline 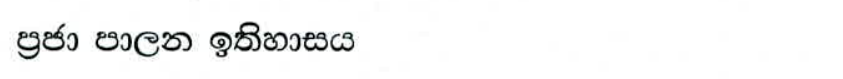 & - ુర్రం \\
\hline 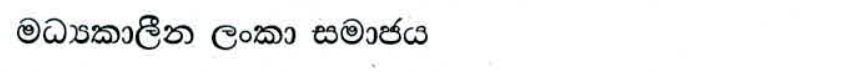 & - అڤుs \\
\hline 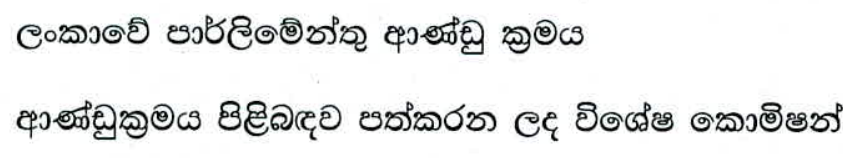 & - еовл⿻рэי \\
\hline 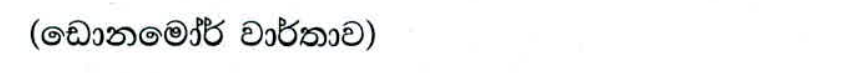 & 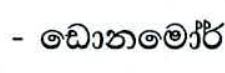 \\
\hline 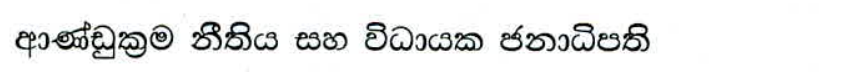 & - ६ృశాట్ర \\
\hline
\end{tabular}




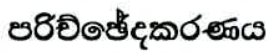

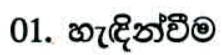

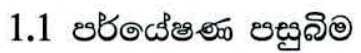

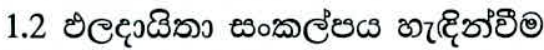

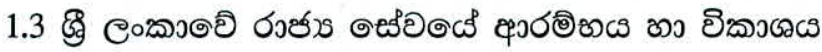

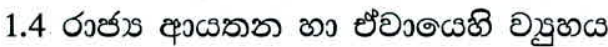

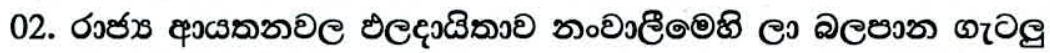

2.1 б.రుక ఢ ఢ

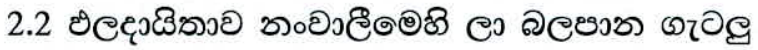

2.2.1 జ జర్రอ తికిటి

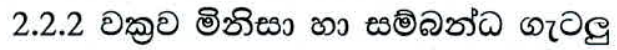

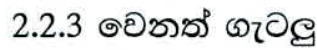

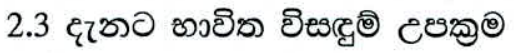

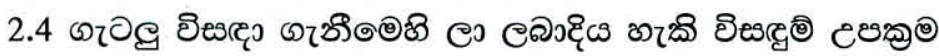

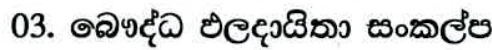

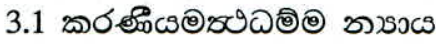

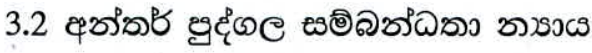

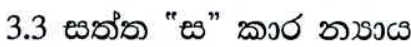

3.3.1 ผంฉిย์

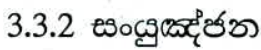

3.3.3 ผะอิఎงท

3.3.4 జอิత్రవి

3.3.5 ๕్రటివాఎง

3.3.6 ผอิвงอง

3.3.7 ผఠఅ๐์ญซూ 


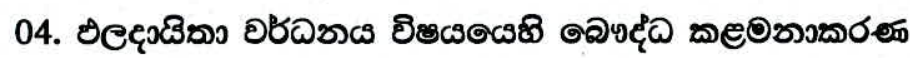

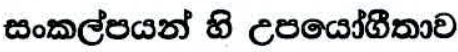

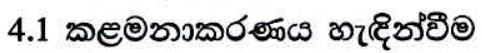

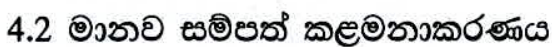

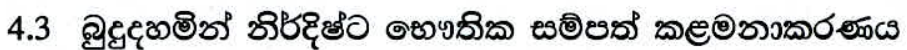

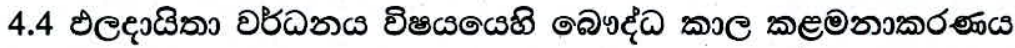

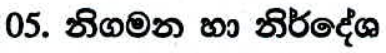

$349-357$

ఢాక్రివ అ్రకార

358-364

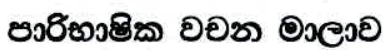

$365-368$

cogsion

$369-382$ 
1. ซశ్ุిรారిఠ

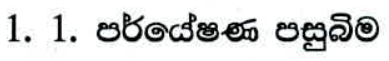

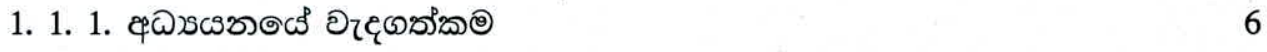

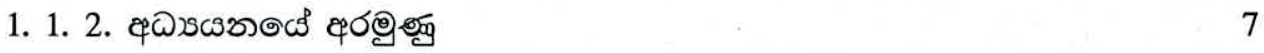

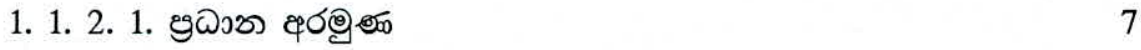

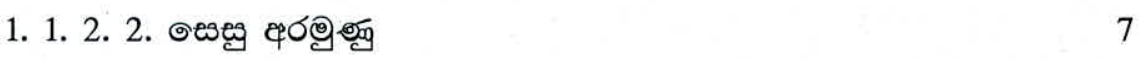

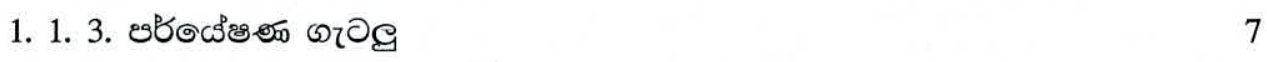

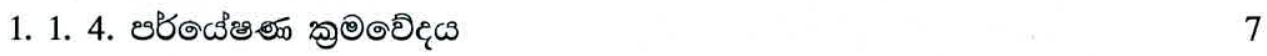

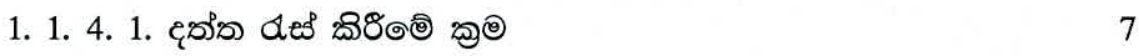

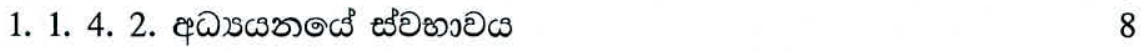

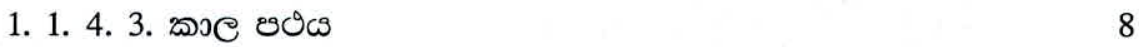

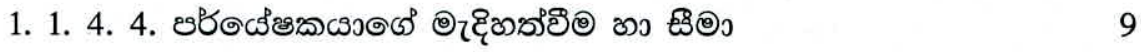

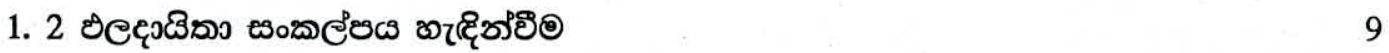

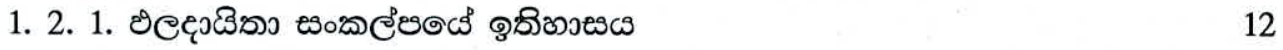

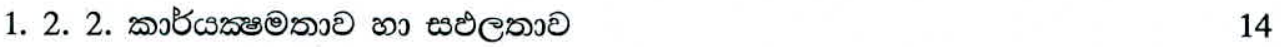

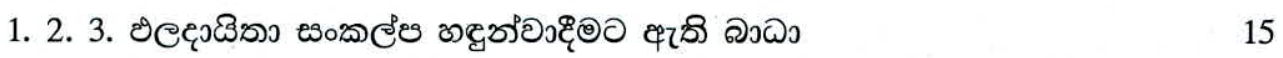

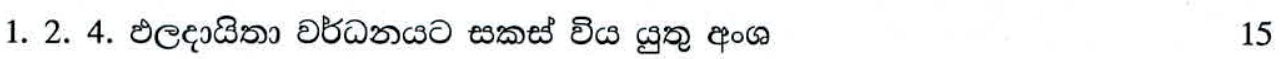

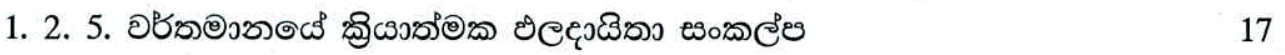

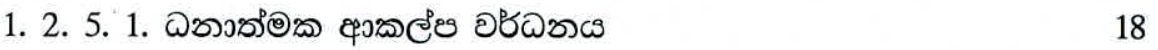

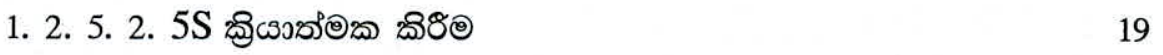

1. 2. 5. 2. 1. ๑ఱిరి (๑5ిరిఠ, ఱంలిదిమ ออ) 20

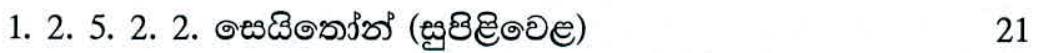

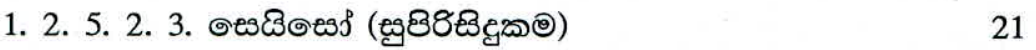

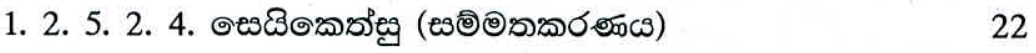

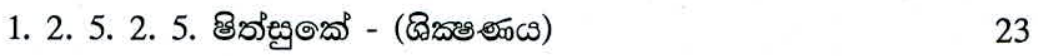




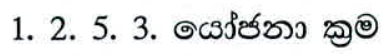

1. 2. 5. 4. พร์ธ่อ ฉอ

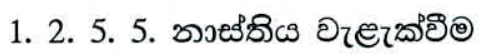

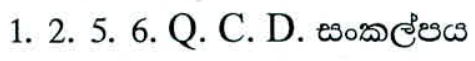

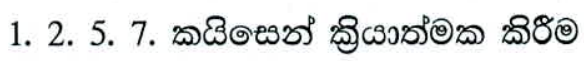

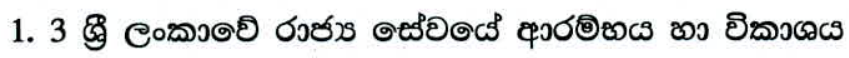

26

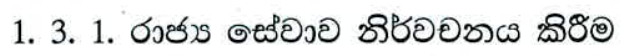
26

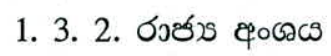
26

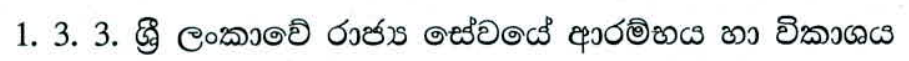
29

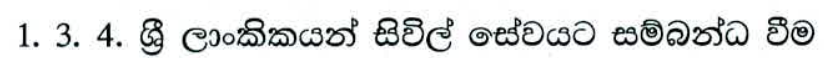
32

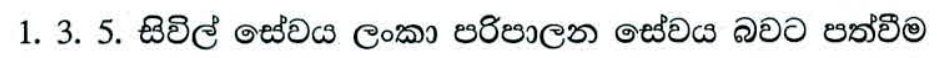
34

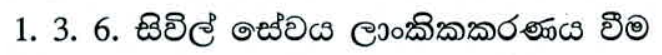
35

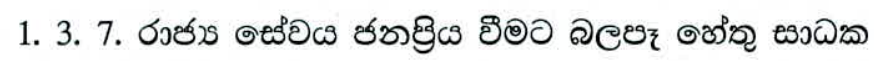
36

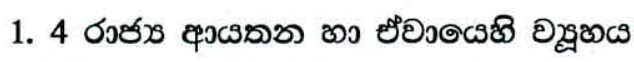
37

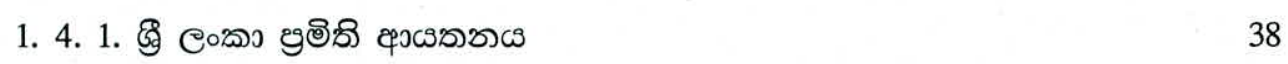

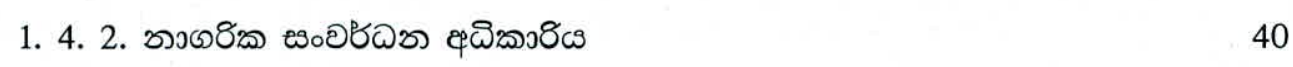

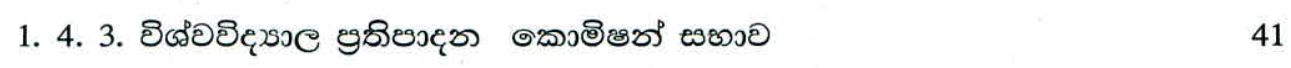

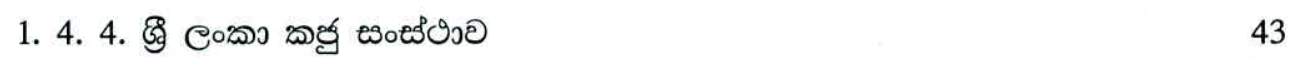

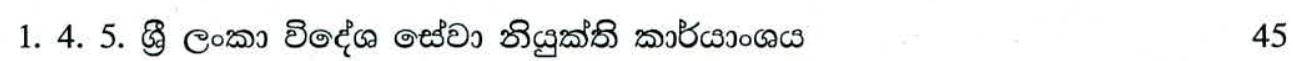

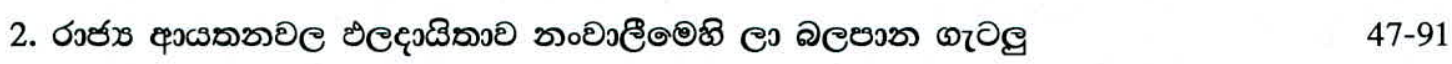

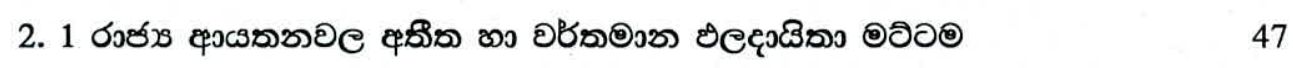

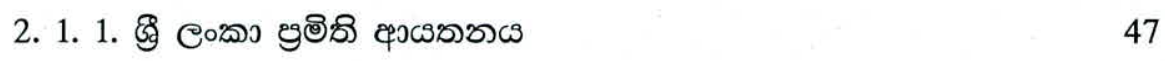

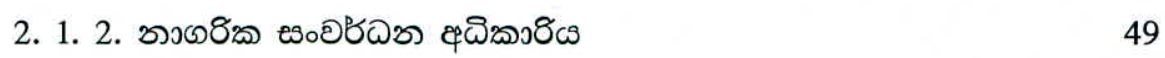

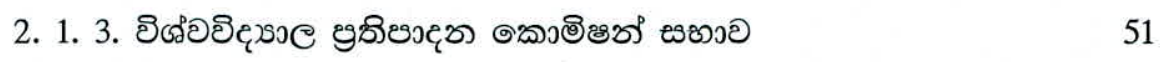

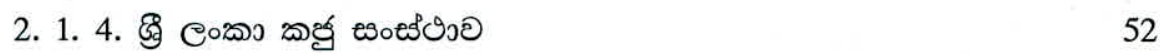




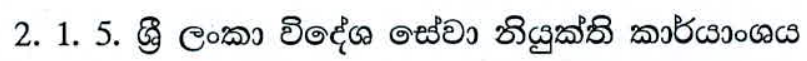

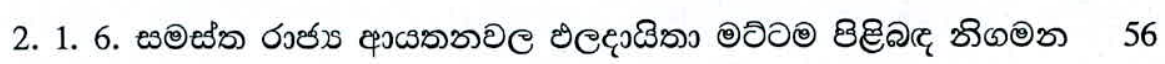

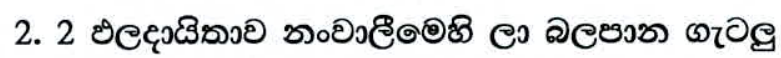

2. 2.1 ๘ช్రอ ฮెకిణ

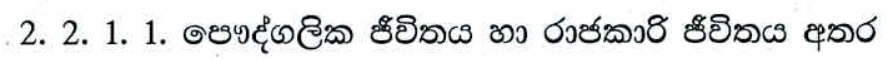

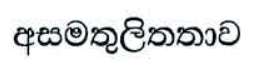

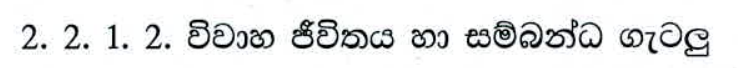
58

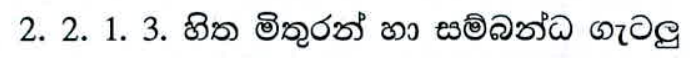
59

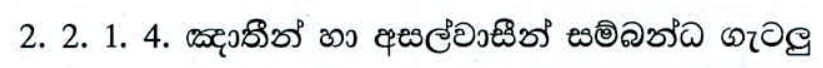
59

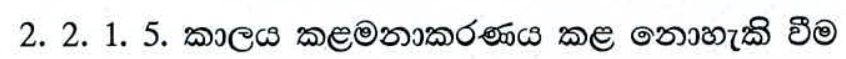
60

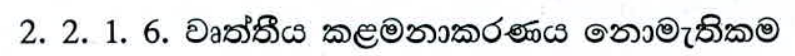
60

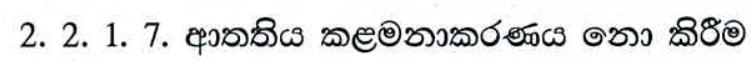
61

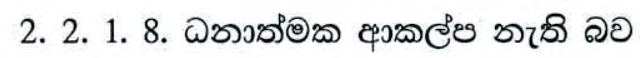
62

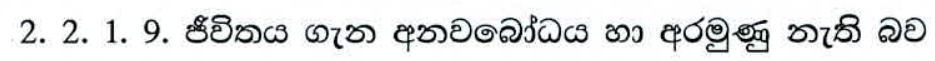
62

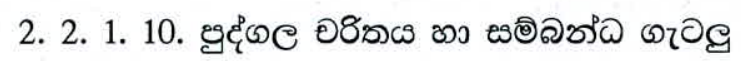

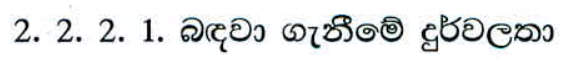

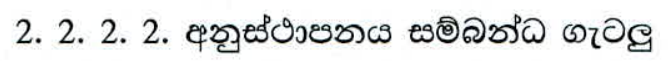
69

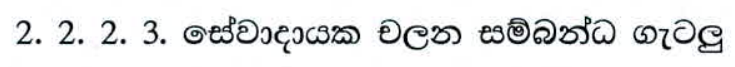
70

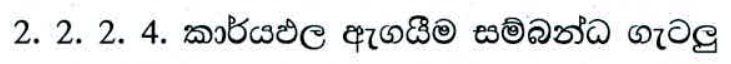
74

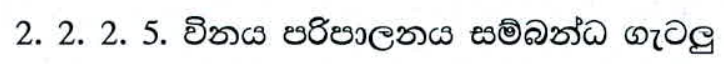
75

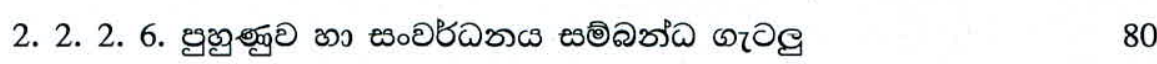

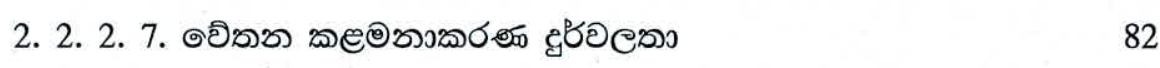

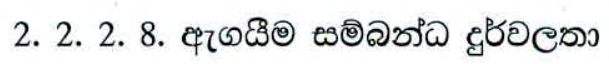

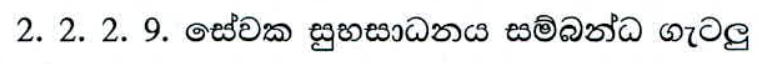
83

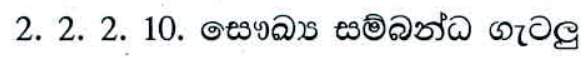
85 


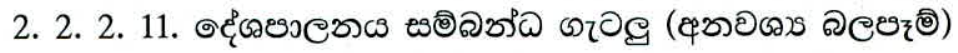

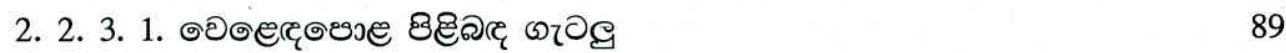

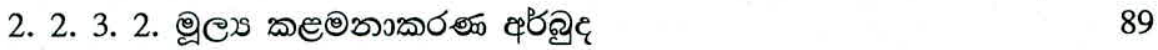

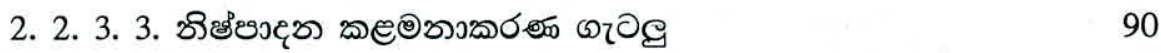

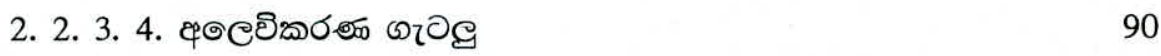

2. 2. 3. 5. ผืองรงలిฉ ตีอย 90

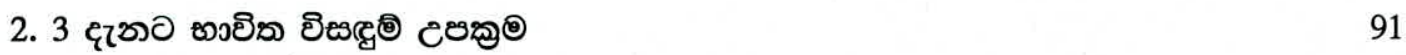

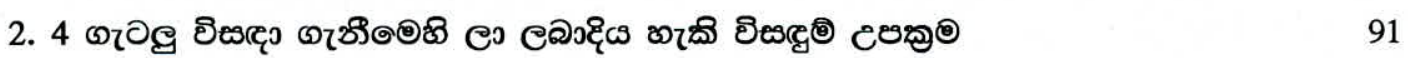

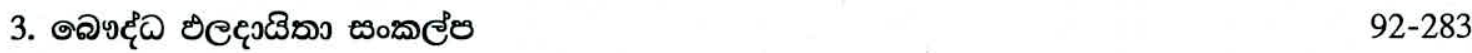

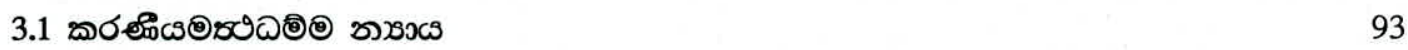

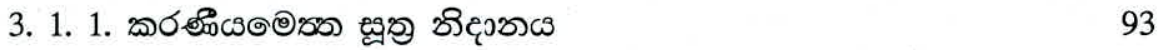

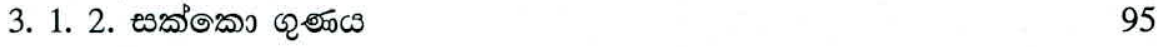

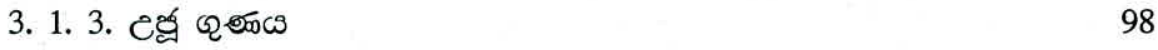

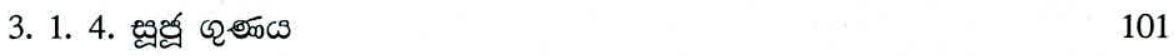

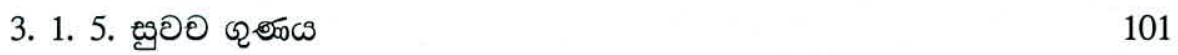

3. 1. 6. ๑ृ્द ออ 104

3. 1. 7. ๕ฺถిองร ออ 106

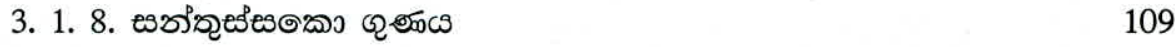

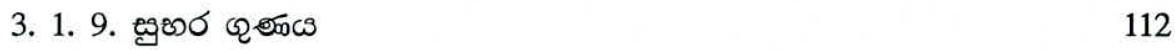

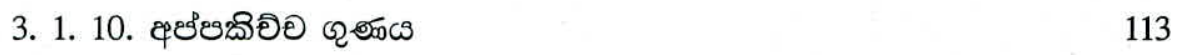

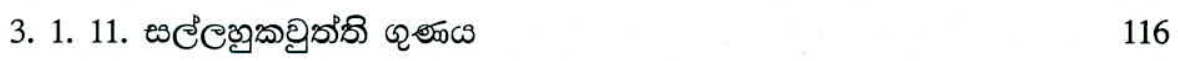

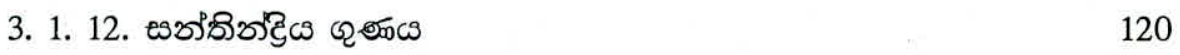

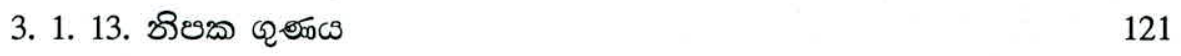

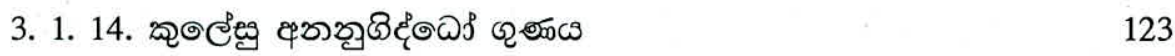




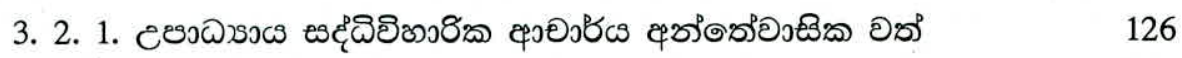

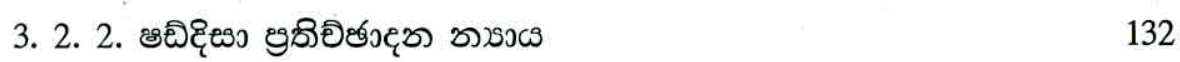

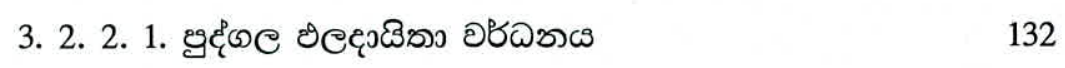

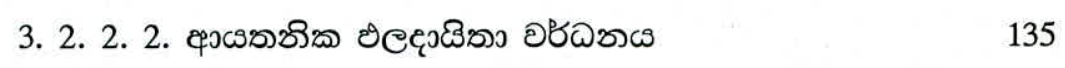

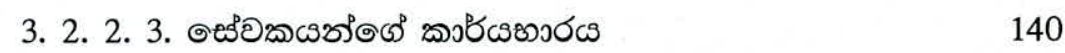

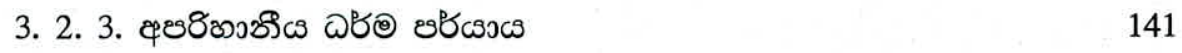

3. 2. 3. 1. ชివర ๔టాలిల 141

3. 2. 3. 2. ๓อธి ผอిชร์ต ออ 142

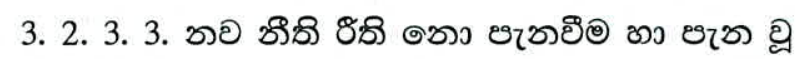

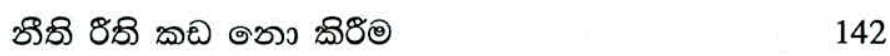

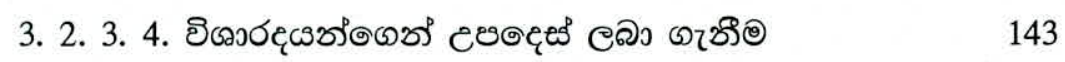

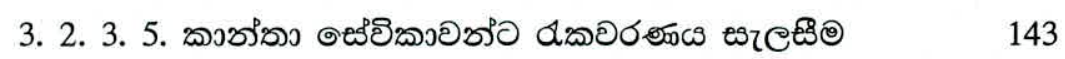

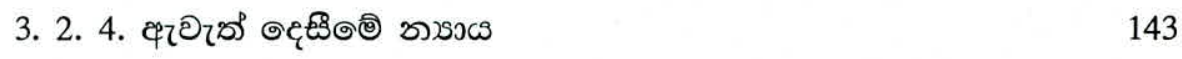

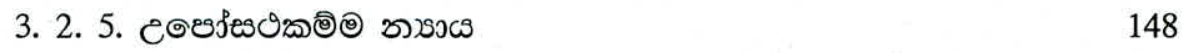

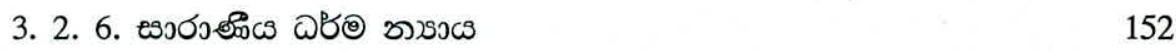

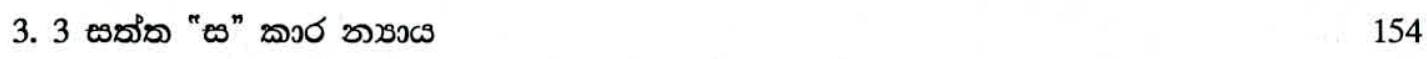

3. 3. 1. ผింชిర 154

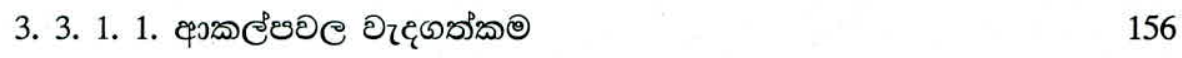

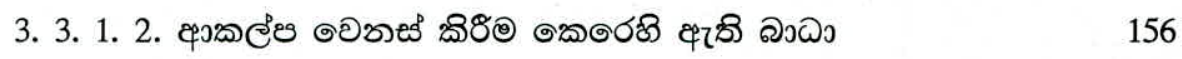

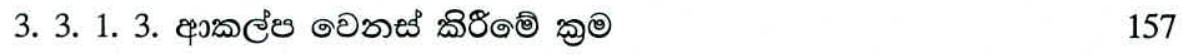

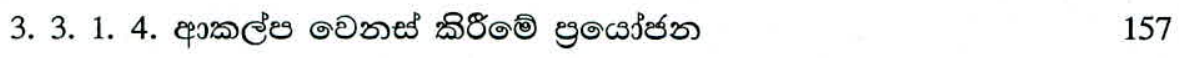

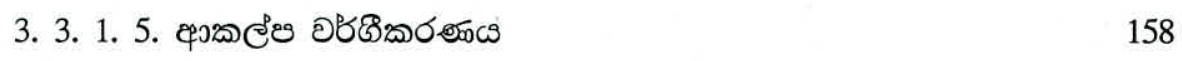

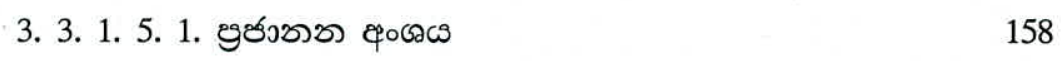

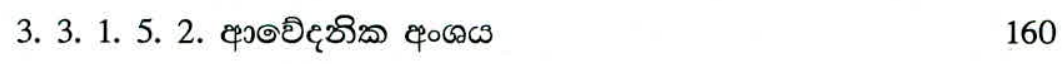

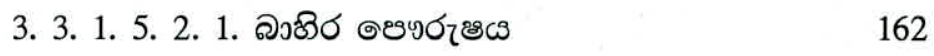

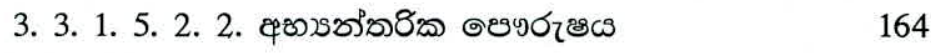




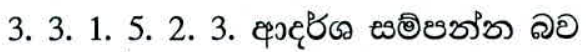

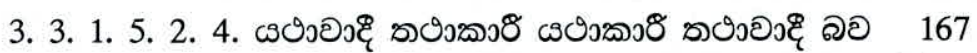

3. 3. 1. 5. 2. 5. ๒งళร вงరిణต 171

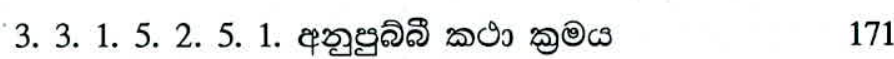

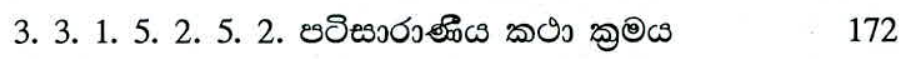

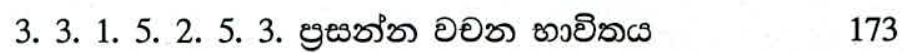

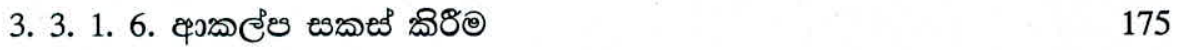

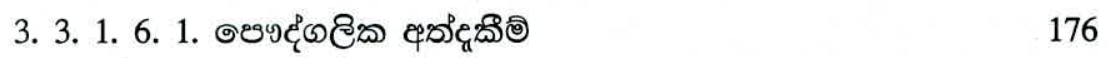

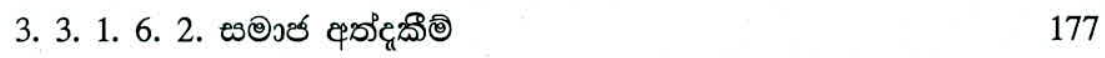

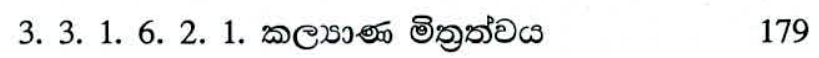

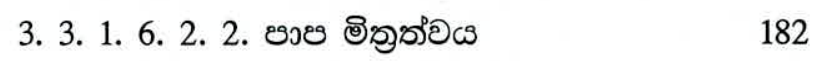

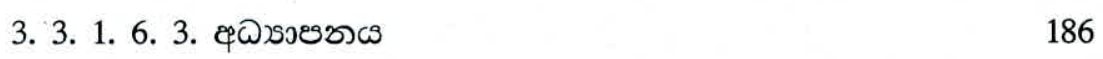

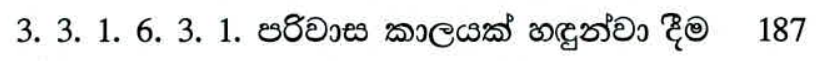

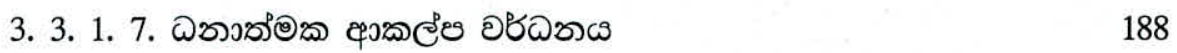

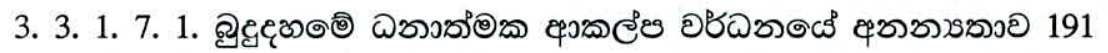

3. 3. 2. అం.

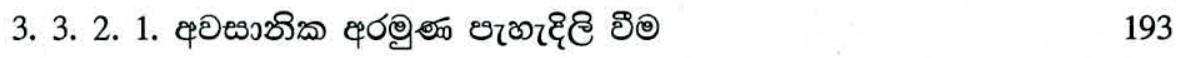

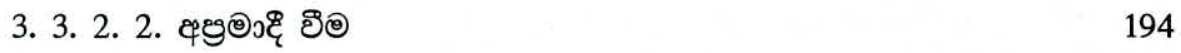

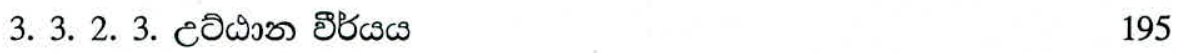

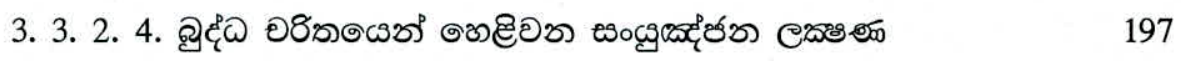

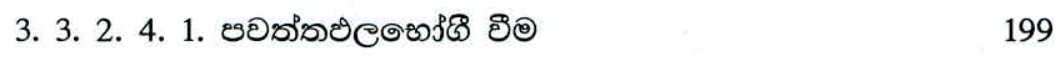

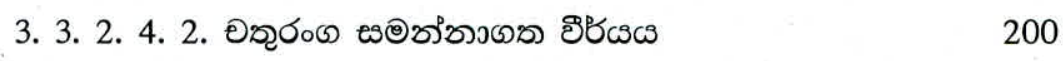

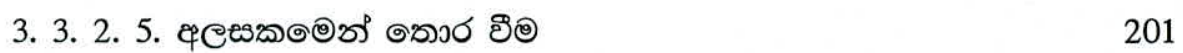

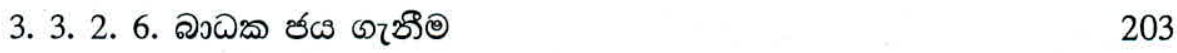

3. 3. 2. 7. ๑อณึอ 203 


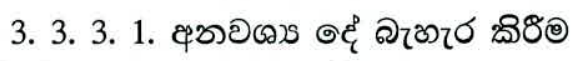

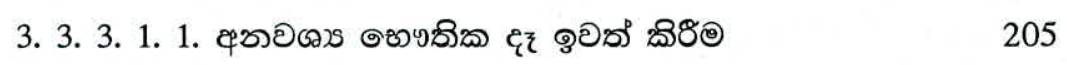

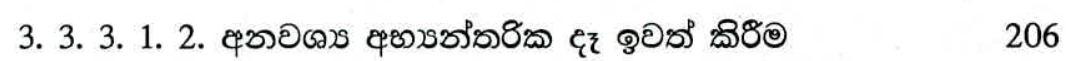

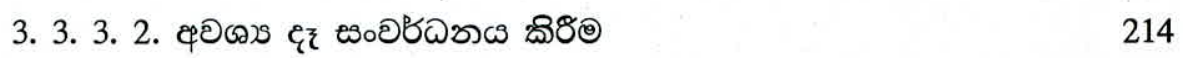

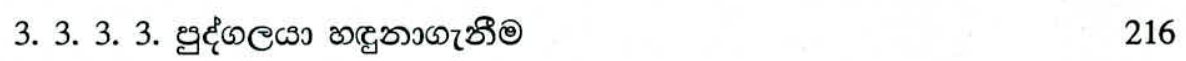

3. 3. 4. ๒ఠిఅవి 219

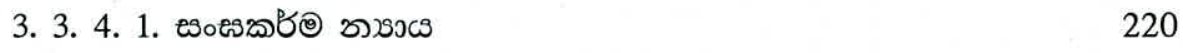

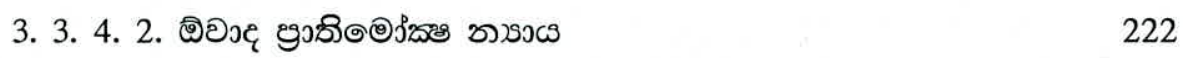

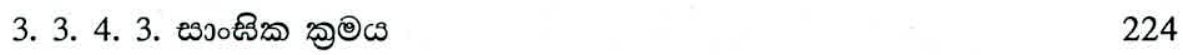

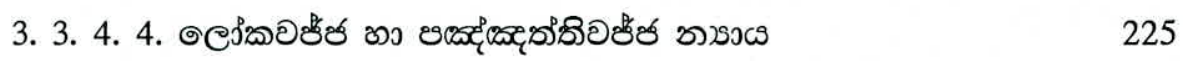

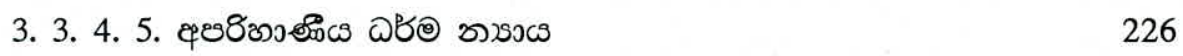

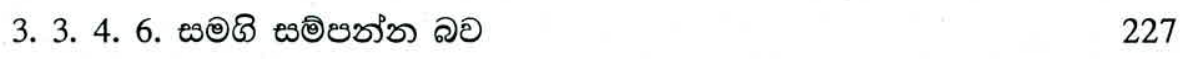

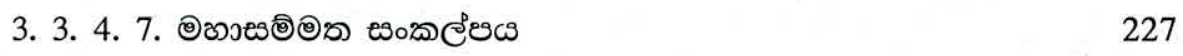

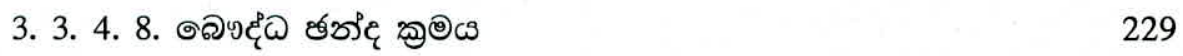

3. 3. 5. ตุบผిฉญอง 231

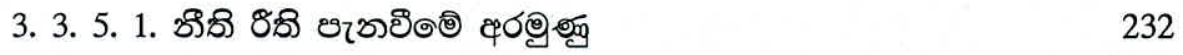

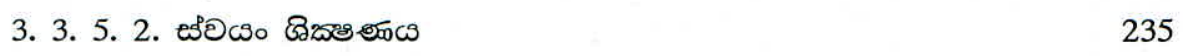

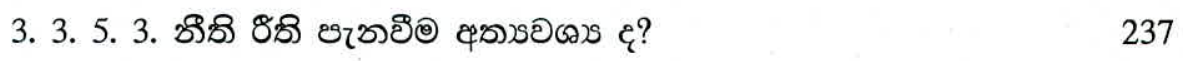

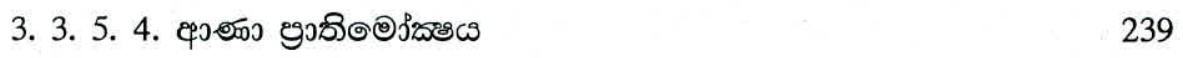

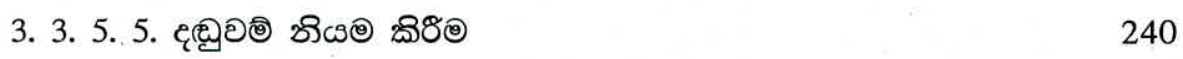

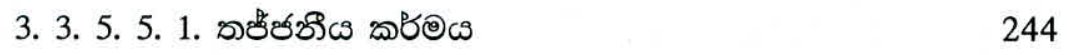

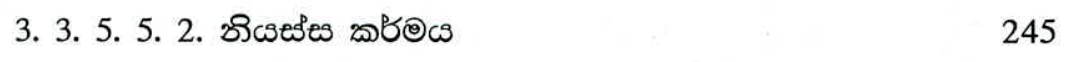

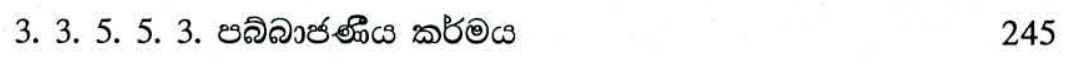

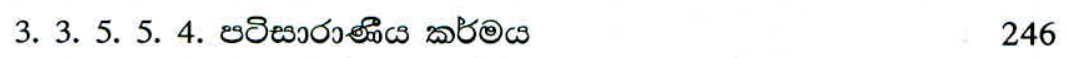

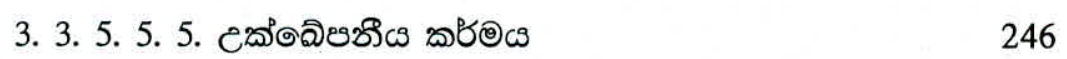

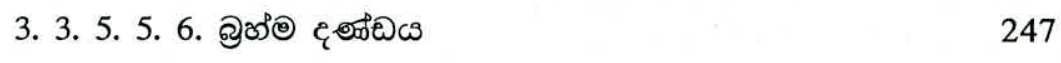




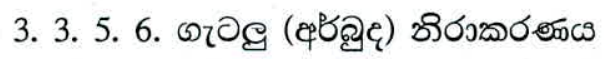

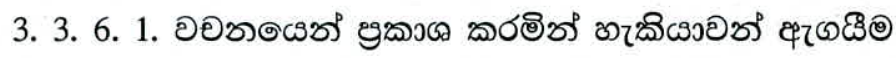

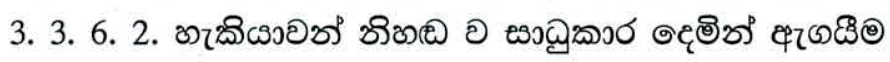

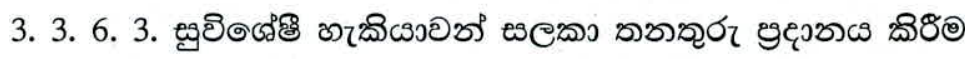

3. 3. 6. 4. ఈచిది

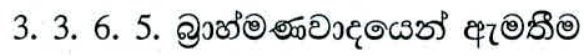

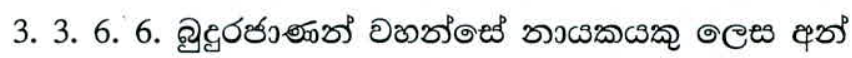

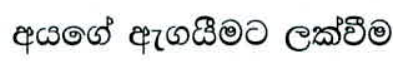

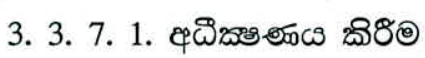

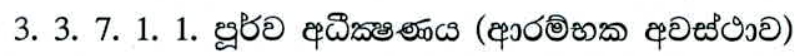

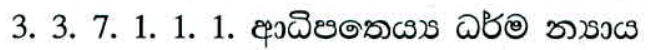
269

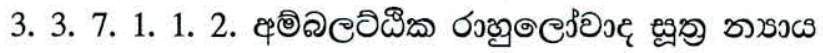

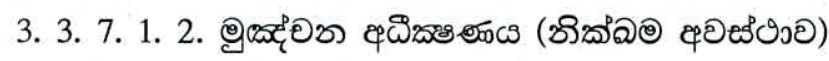

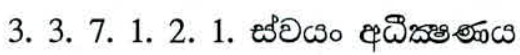

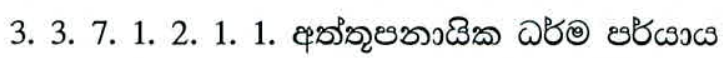

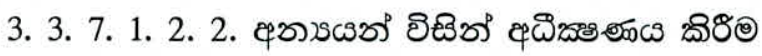

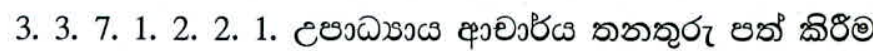

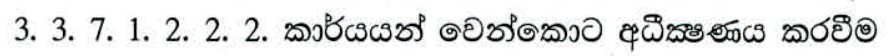

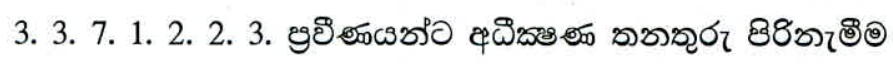

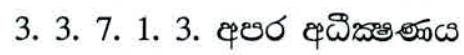

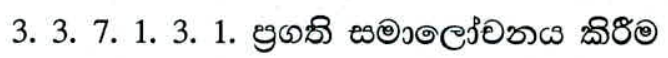
276

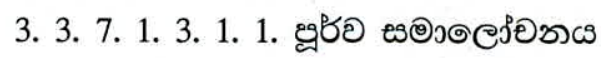
276

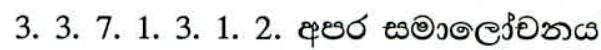
277 


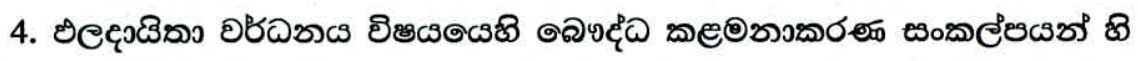

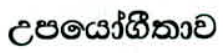

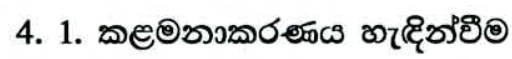

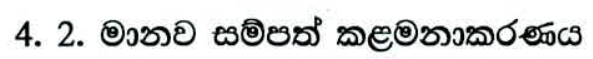

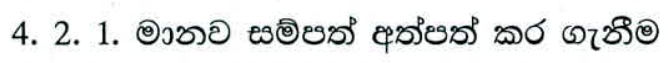

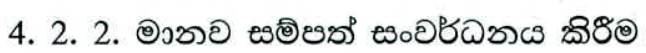

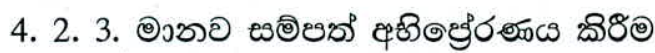

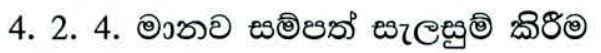

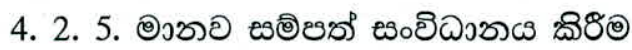

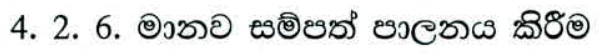

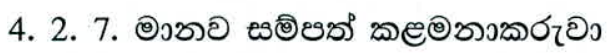

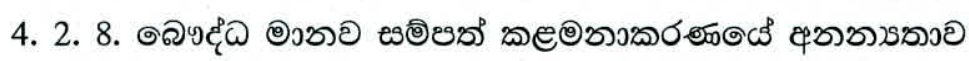

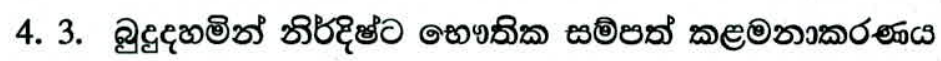

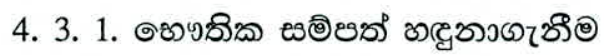

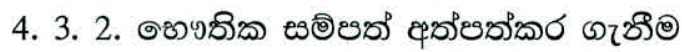

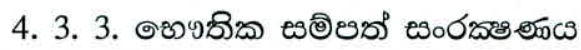
320

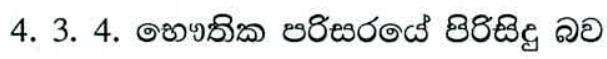

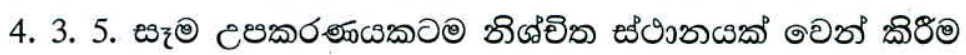

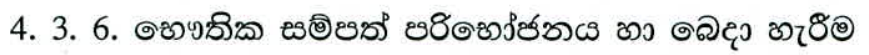

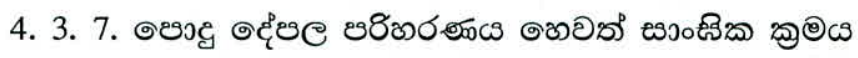

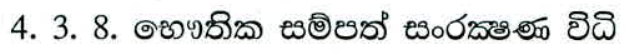

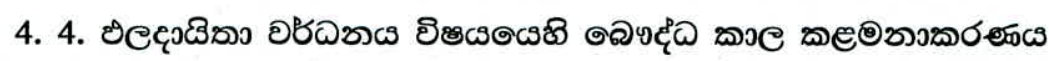

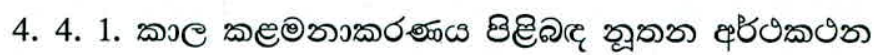

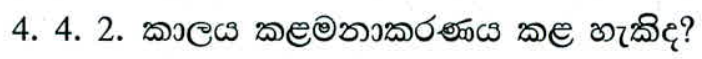

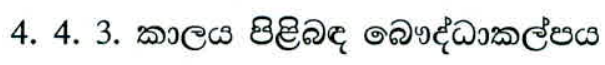

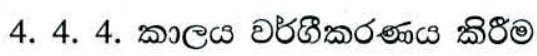

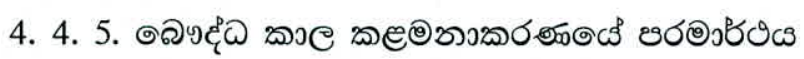




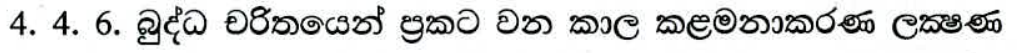

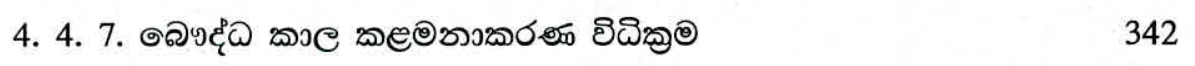

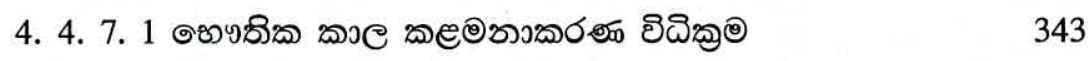

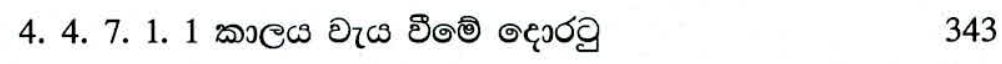

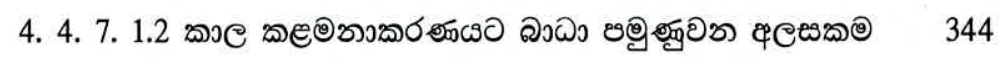

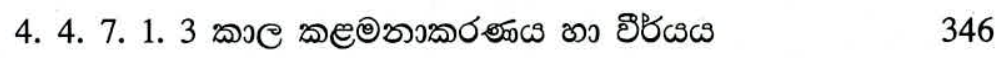

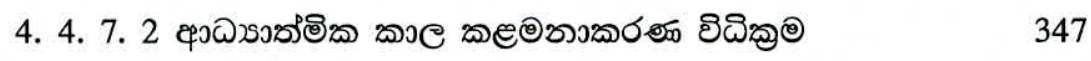

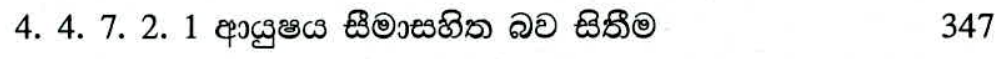

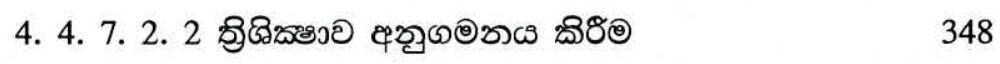

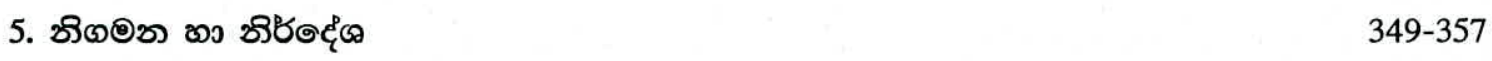

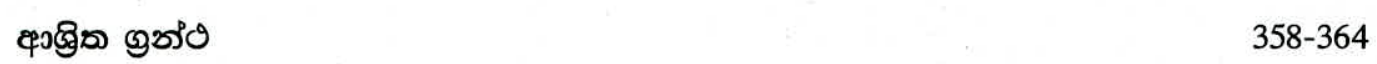

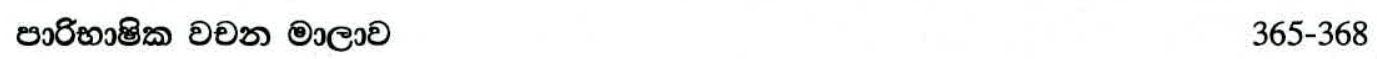

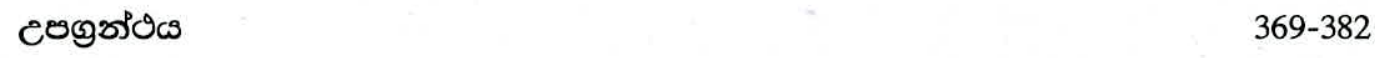

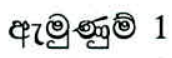

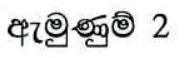

타이유요 3

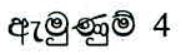

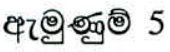

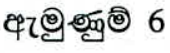

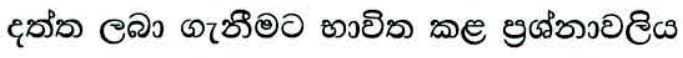

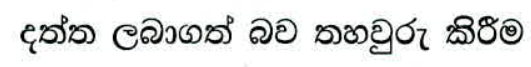




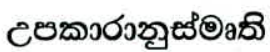

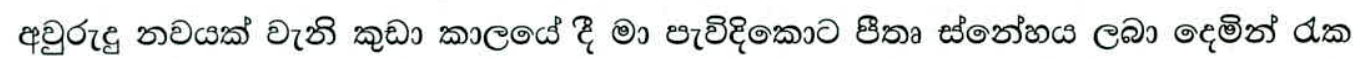

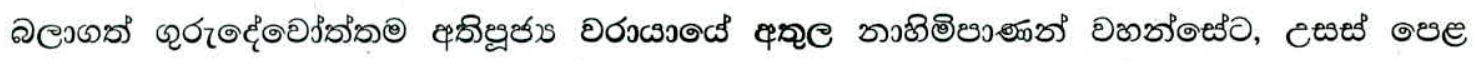

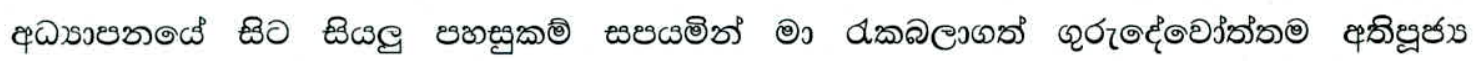

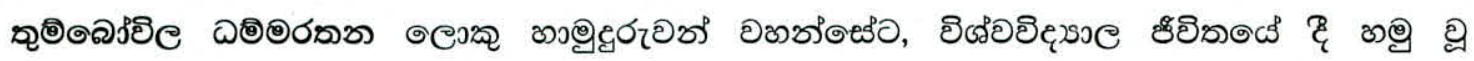

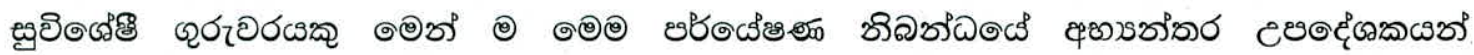

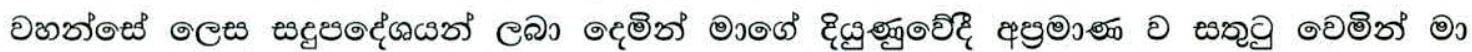

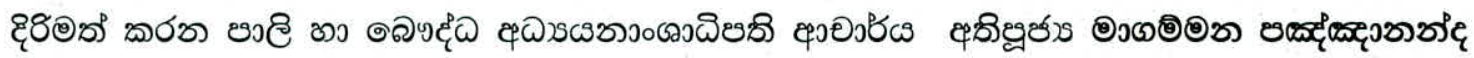

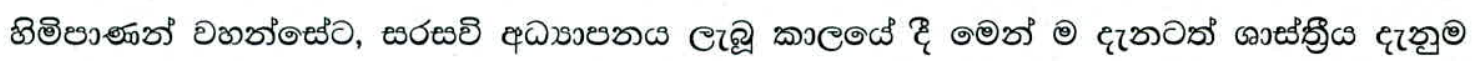

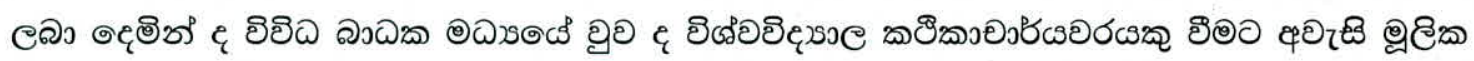

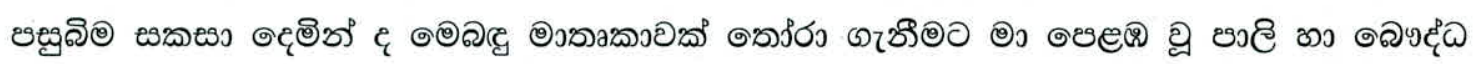

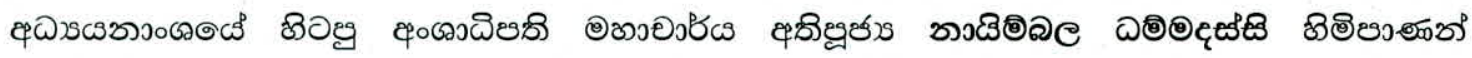

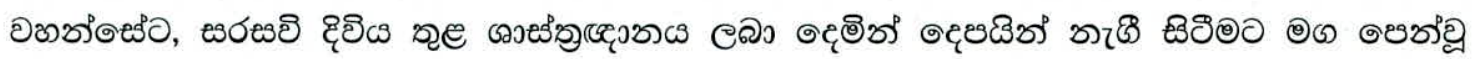

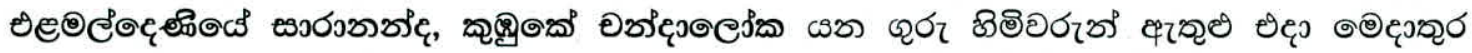

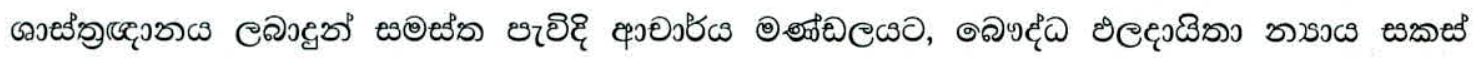

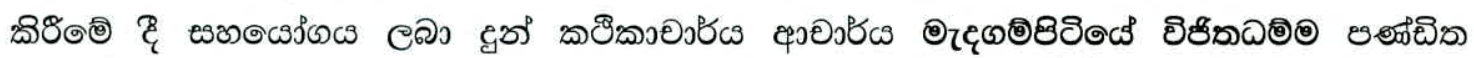

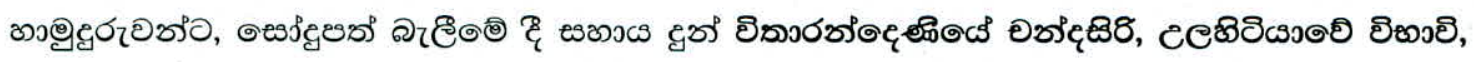

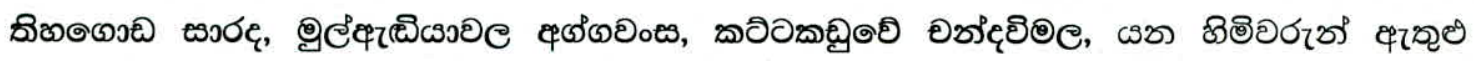

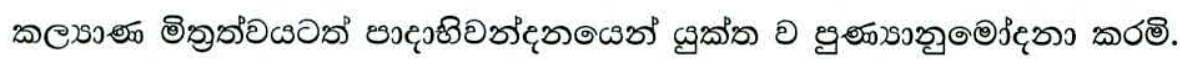

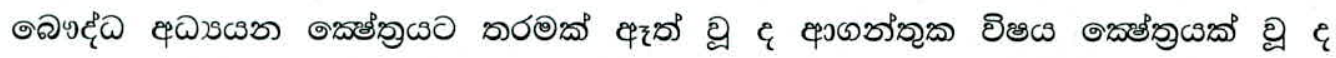

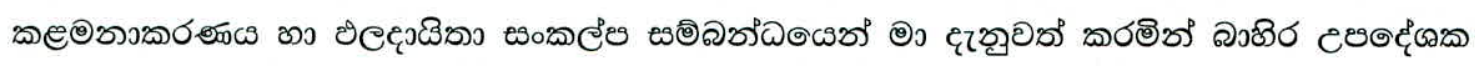

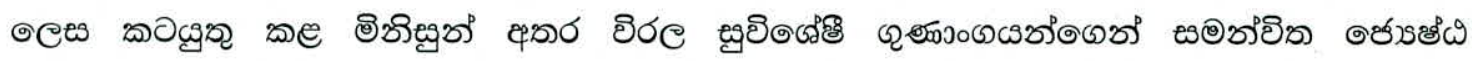

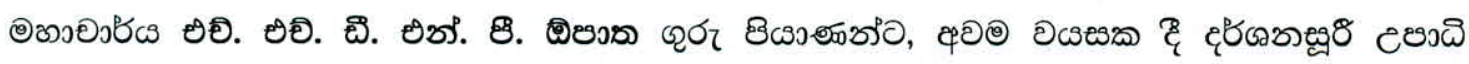

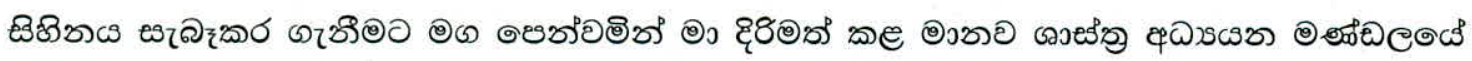

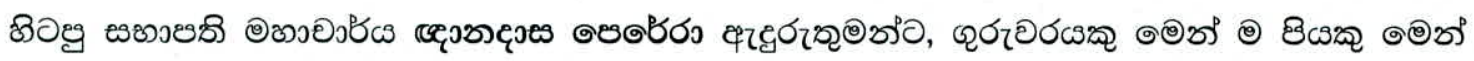

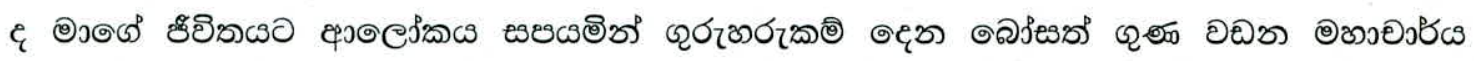




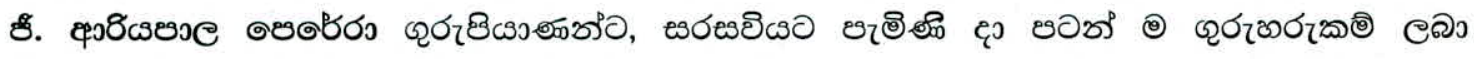

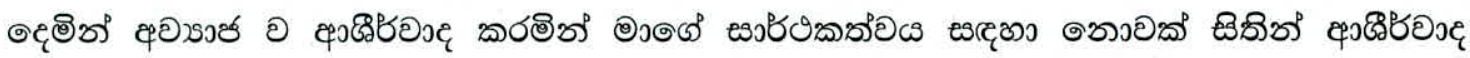

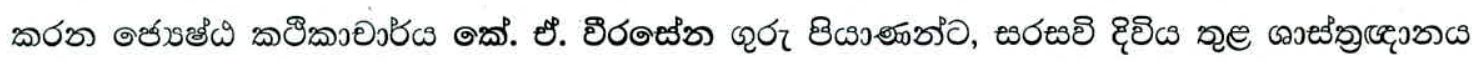

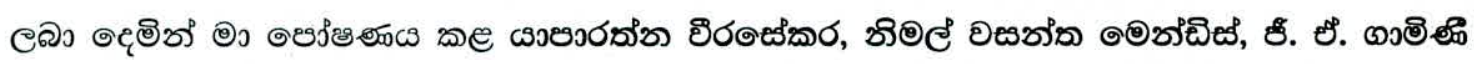

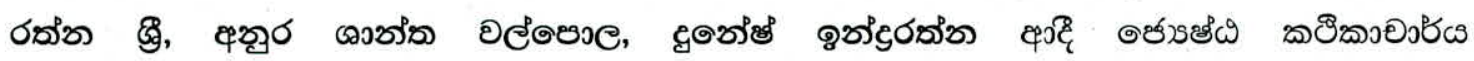

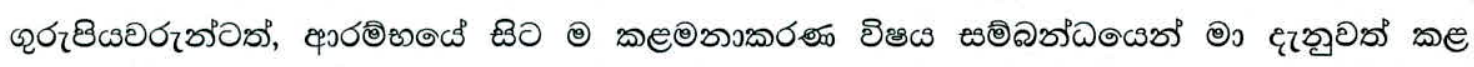

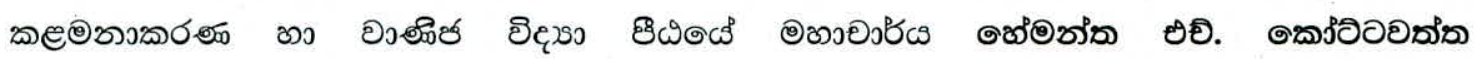

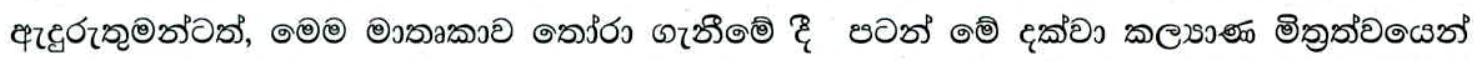

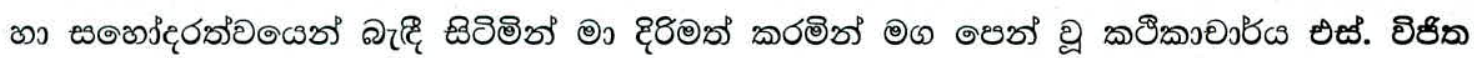

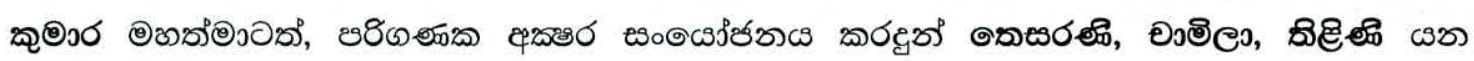

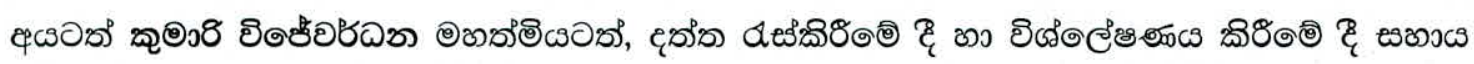

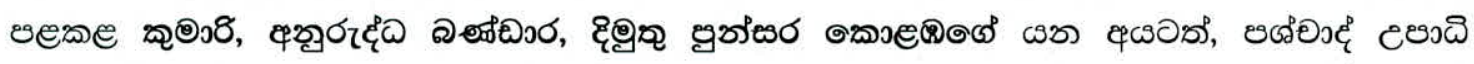

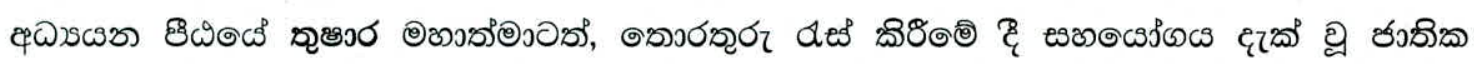

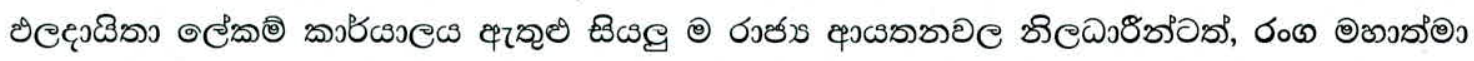

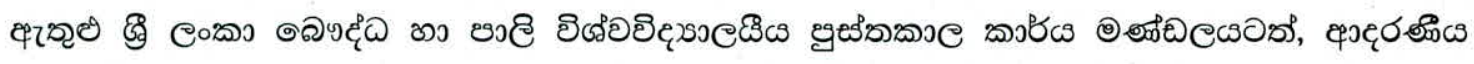

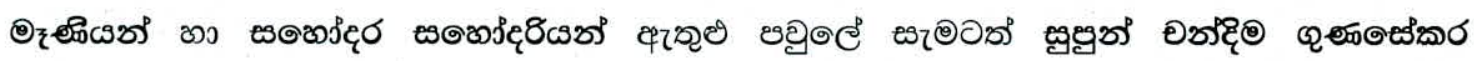

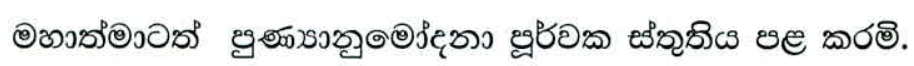




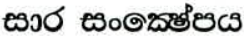

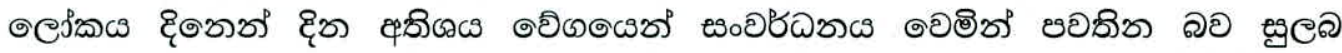

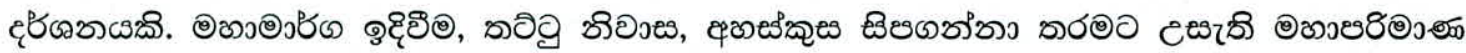

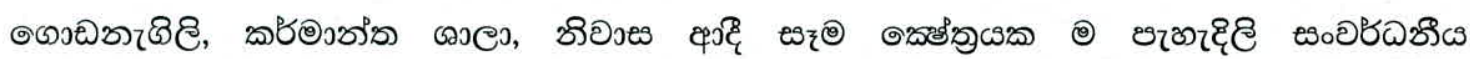

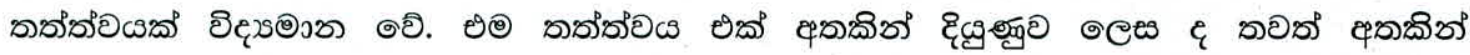

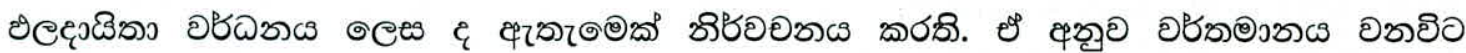

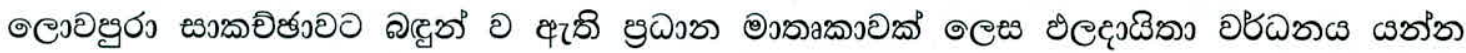

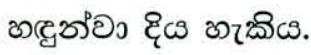

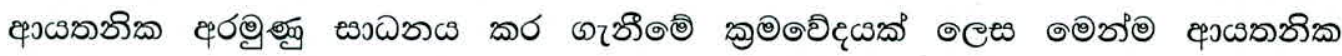

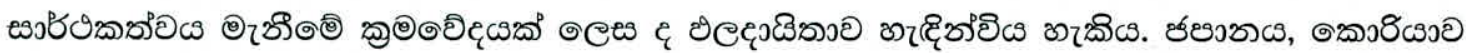

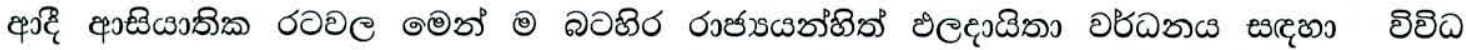

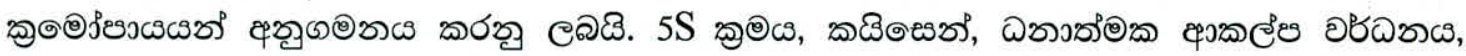

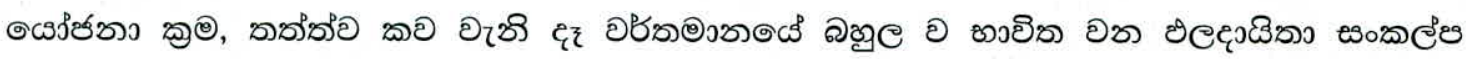

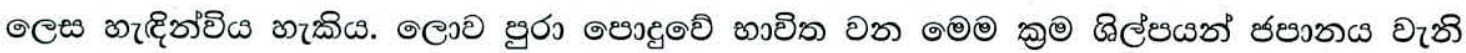

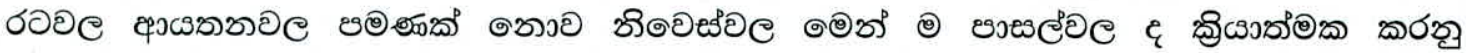

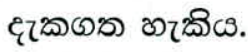

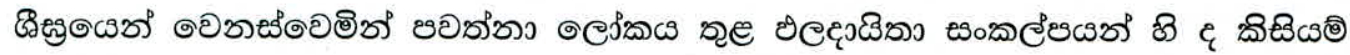

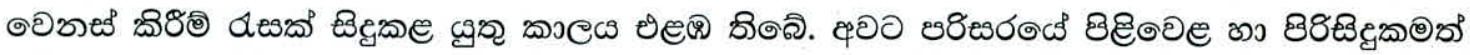

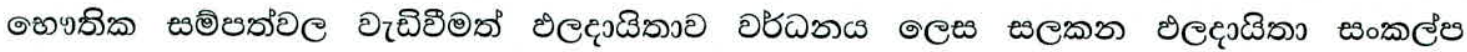

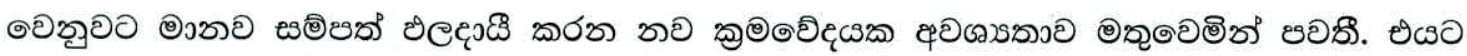

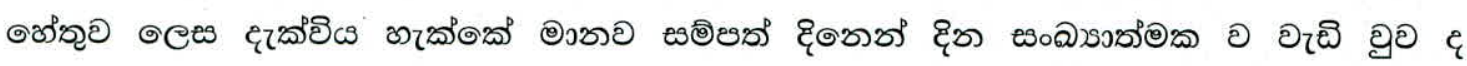

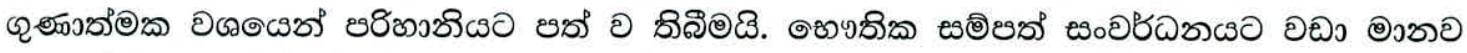

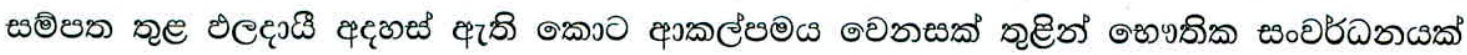

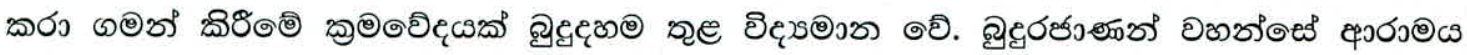

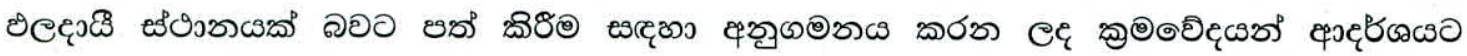




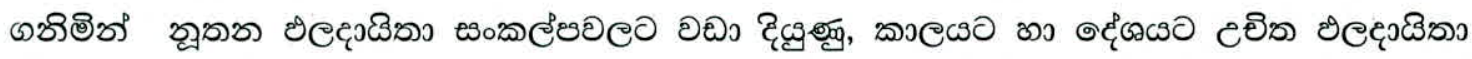

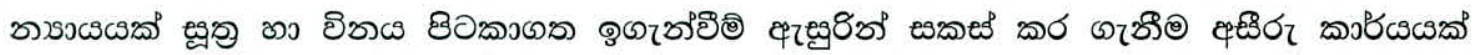

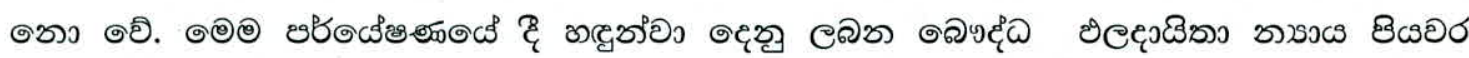

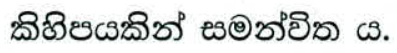

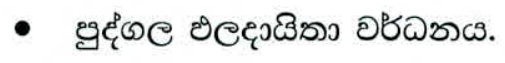

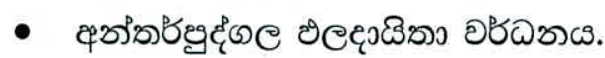

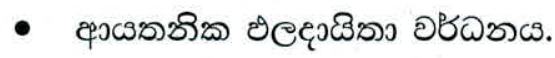

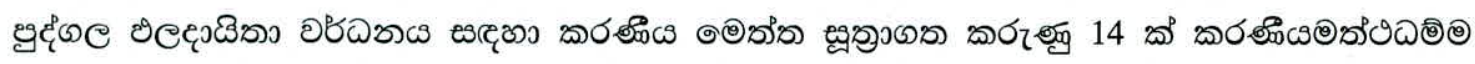

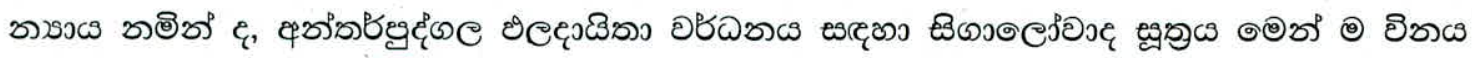

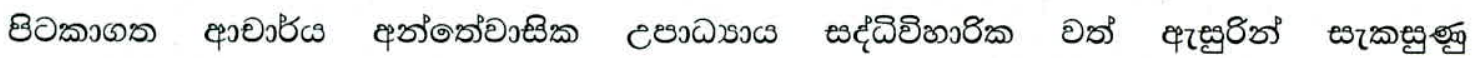

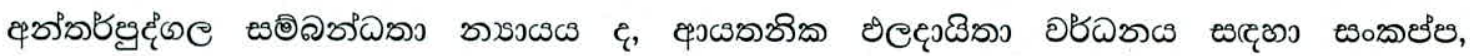

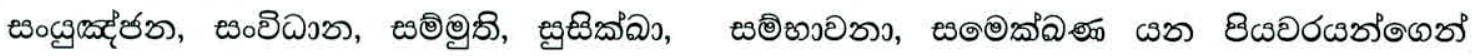

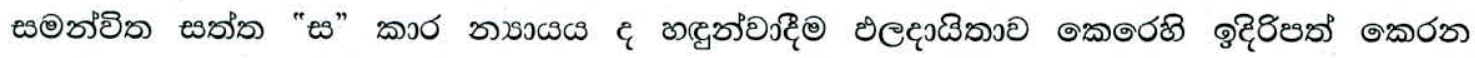

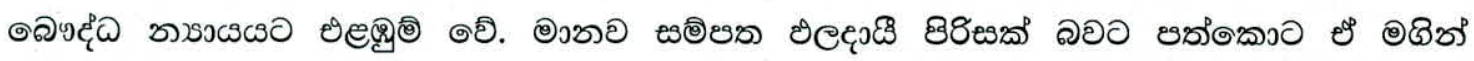

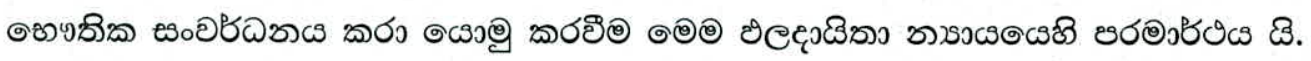

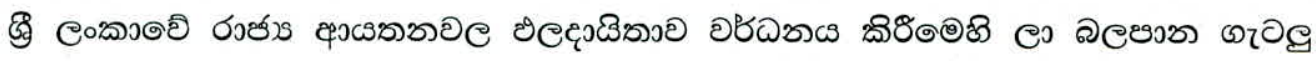

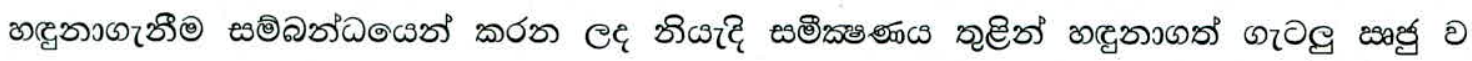

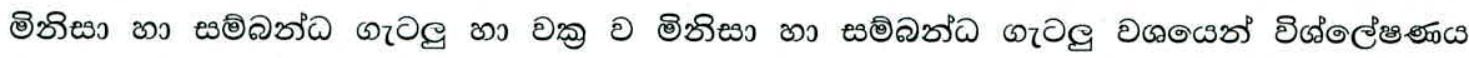

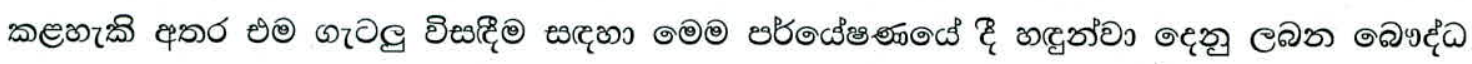

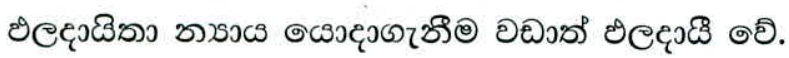

